\title{
Virus-host interactomics: new insights and opportunities for antiviral drug discovery
}

\author{
Benoît de Chassey ${ }^{1}$, Laurène Meyniel-Schicklin', Jacky Vonderscher ${ }^{1}$, Patrice Andrée ${ }^{2,3,4}$ and Vincent Lotteau ${ }^{3,4^{*}}$
}

\begin{abstract}
The current therapeutic arsenal against viral infections remains limited, with often poor efficacy and incomplete coverage, and appears inadequate to face the emergence of drug resistance. Our understanding of viral biology and pathophysiology and our ability to develop a more effective antiviral arsenal would greatly benefit from a more comprehensive picture of the events that lead to viral replication and associated symptoms. Towards this goal, the construction of virus-host interactomes is instrumental, mainly relying on the assumption that a viral infection at the cellular level can be viewed as a number of perturbations introduced into the host protein network when viral proteins make new connections and disrupt existing ones. Here, we review advances in interactomic approaches for viral infections, focusing on high-throughput screening (HTS) technologies and on the generation of high-quality datasets. We show how these are already beginning to offer intriguing perspectives in terms of virus-host cell biology and the control of cellular functions, and we conclude by offering a summary of the current situation regarding the potential development of host-oriented antiviral therapeutics.
\end{abstract}

\section{Introduction}

Conventional drug therapies against human viruses mainly target viral enzymes (Table 1). The repertoire of druggable viral proteins and corresponding small molecules is extremely limited, and a major drawback in the use of these direct-acting drugs is the emergence of resistance [1-3]. Because of these limitations, antiviral drug discovery is beginning to explore the possibility to develop host-oriented molecules acting on cellular functions that are essential for viruses to replicate [4]. Indeed, viruses are obligate intracellular parasites, and, as such, they rely on cellular functions to replicate. They have evolved a variety of strategies to manipulate the cellular machinery for their own benefit as well as to counteract or even to use host immune defenses. As the vast majority of cellular functions is supported by interacting proteins, the manipulation of cellular processes by viruses mainly results from physical interactions between viral and host proteins [5]. Therefore, a virus-host (VH) interactome, interpreted in the context of the host interactome, allows the identification of a network of cellular proteins and associated functions that are essential in

\footnotetext{
* Correspondence: vincent.lotteau@inserm.fr

${ }^{3}$ CIRI, Université de Lyon, Lyon 69365, France

${ }^{4}$ Inserm, U1111, Lyon 69365, France

Full list of author information is available at the end of the article
}

the virus life-cycle. These proteins can be considered as new antiviral targets, and some of them could well be functionally manipulated with new small molecules, repurposed drugs (Food and Drug Administration (FDA)approved or experimental molecules) or with rescued drugs from abandoned pharmaceutical pipelines [4,6-9].

Until 2007, VH protein-protein interactions (PPIs) had been explored with low-scale experiments focusing on a particular viral protein or a specific biological process. The recent application of high-throughput screening (HTS) methods to the establishment of VH interactomes has not only greatly enriched the landscape of VH PPI but has also yielded an explosion in candidate drug targets. Furthermore, substantial efforts have been made to integrate both low- and high-throughput data in various databases (Table 2), favoring the transition from a reductionist to an integrative approach to understanding viral infection.

Altogether, the wealth of VH PPI data has already provided access to nearly complete interactomes for several viruses that are of public health concern, including influenza virus, hepatitis $\mathrm{C}$ virus (HCV) and dengue virus [10]. Integration of this information into knowledge of the uninfected human protein network highlights key topological and functional features of the 'infected network'. High-throughput approaches also allow comparative 
Table 1 Current FDA-approved antivirals and their targets

\begin{tabular}{|c|c|c|c|c|c|}
\hline DrugBank ID & Name & Type & $\begin{array}{l}\text { Year of first approval } \\
\text { as an antiviral }\end{array}$ & Virus & Target(s) \\
\hline DB00249 & Idoxuridine & Small molecule & 1963 & HSV & DNA, viral thymidine kinase \\
\hline DB00915 & Amantadine & Small molecule & 1966 & Influenza virus & Viral matrix protein $\mathrm{M} 2$ \\
\hline DB00987 & Cytarabine & Small molecule & 1969 & Herpesviruses & $\begin{array}{l}\text { Human cytidine deaminase, human } \\
\text { cytochrome P450 3A4, human deoxycytidine } \\
\text { kinase, human 5'-nucleotidase, human } \\
\text { deoxycytidylate deaminase }\end{array}$ \\
\hline DB00194 & Vidarabine & Small molecule & 1976 & HSV, VZV & $\begin{array}{l}\text { Viral DNA polymerase, viral thymidine } \\
\text { kinase, DNA }\end{array}$ \\
\hline DB00811 & Ribavirin & Small molecule & 1980 & HCV, RSV & $\begin{array}{l}\text { Human inosine- } 5^{\prime} \text {-monophosphate } \\
\text { dehydrogenase } 1 \text {, human adenosine kinase, } \\
\text { human cytosolic purine } 5^{\prime} \text {-nucleotidase }\end{array}$ \\
\hline DB00787 & Aciclovir & Small molecule & 1982 & HSV1, HSV2, VZV & Viral DNA polymerase, viral thymidine kinase \\
\hline DB00495 & Zidovudine & Small molecule & 1987 & HIV & Viral reverse transcriptase \\
\hline DB01004 & Ganciclovir & Small molecule & 1989 & CMV & $\begin{array}{l}\text { Viral DNA polymerase, viral thymidine } \\
\text { kinase, DNA }\end{array}$ \\
\hline- & Tromantadine & Small molecule & Later than 1990 & HSV & Human glycoproteins \\
\hline- & Interferons & Proteins & $1990 \mathrm{~s}$ & Hepatitis, etc. & Human IFNARs \\
\hline DB00900 & Didanosine & Small molecule & 1991 & HIV & Viral reverse transcriptase \\
\hline DB00529 & Foscarnet & Small molecule & 1991 & CMV, HSV & Viral DNA polymerase \\
\hline DB00943 & Zalcitabine & Small molecule & 1992 & HIV & Viral reverse transcriptase \\
\hline DB00426 & Famciclovir & Small molecule & 1994 & HSV, VZV & Viral DNA polymerase \\
\hline DB00478 & Rimantadine & Small molecule & 1994 & Influenza virus & Viral matrix protein $\mathrm{M} 2$ \\
\hline DB00649 & Stavudine & Small molecule & 1994 & HIV & Viral reverse transcriptase \\
\hline DB00709 & Lamivudine & Small molecule & 1995 & HIV, HBV & Viral reverse transcriptase \\
\hline DB00432 & Trifluridine & Small molecule & 1995 & HSV & Viral thymidylate kinase \\
\hline DB00577 & Valaciclovir & Small molecule & 1995 & HSV, VZV, CMV & Viral DNA polymerase, viral thymidine kinase \\
\hline DB00369 & Cidofovir & Small molecule & 1996 & CMV & Viral DNA polymerase \\
\hline DB00224 & Indinavir & Small molecule & 1996 & HIV & Viral protease \\
\hline DB00238 & Nevirapine & Small molecule & 1996 & HIV & Viral reverse transcriptase \\
\hline DB00299 & Penciclovir & Small molecule & 1996 & HSV & $\begin{array}{l}\text { Viral DNA polymerase, viral thymidine } \\
\text { kinase }\end{array}$ \\
\hline DB00503 & Ritonavir & Small molecule & 1996 & HIV & Viral protease \\
\hline DB01232 & Saquinavir & Small molecule & 1996 & HIV & Viral protease \\
\hline DB00705 & Delavirdine & Small molecule & 1997 & HIV & Viral reverse transcriptase \\
\hline DB00220 & Nelfinavir & Small molecule & 1997 & HIV & Viral protease \\
\hline DB01048 & Abacavir & Small molecule & 1998 & HIV & Viral reverse transcriptase \\
\hline DB00625 & Efavirenz & Small molecule & 1998 & HIV & Viral reverse transcriptase \\
\hline- & Fomivirsen & Oligonucleotide & 1998 & CMV & Viral mRNA \\
\hline DB00110 & Palivizumab & $\begin{array}{l}\text { Humanized monoclonal } \\
\text { antibody }\end{array}$ & 1998 & RSV & Viral fusion glycoprotein F0 \\
\hline DB00701 & Amprenavir & Small molecule & 1999 & HIV & Viral protease \\
\hline DB00198 & Oseltamivir & Small molecule & 1999 & Influenza virus & Viral neuraminidase \\
\hline DB00558 & Zanamivir & Small molecule & 1999 & Influenza virus & Viral neuraminidase \\
\hline DB00632 & Docosanol & Small molecule & 2000 & HSV & Viral envelope glycoprotein \\
\hline DB01601 & Lopinavir & Small molecules & 2000 & HIV & Viral protease \\
\hline DB00022 & Peginterferon alfa-2b & Protein & 2001 & $\mathrm{HCV}$ & Human IFNARs \\
\hline DB00300 & Tenofovir & Small molecule & 2001 & HIV, HBV & Viral DNA \\
\hline
\end{tabular}


Table 1 Current FDA-approved antivirals and their targets (Continued)

\begin{tabular}{|c|c|c|c|c|c|}
\hline DB01610 & Valganciclovir & Small molecule & 2001 & CMV & DNA \\
\hline DB00718 & Adefovir Dipivoxil & Small molecule & 2002 & HBV & Viral DNA polymerase \\
\hline DB00008 & Peginterferon alfa-2a & Protein & 2002 & Hepatitis & Human IFNARs \\
\hline DB01072 & Atazanavir & Small molecule & 2003 & HIV & Viral protease \\
\hline DB00879 & Emtricitabine & Small molecule & 2003 & HIV & Viral reverse transcriptase \\
\hline DB00109 & Enfuvirtide & Protein & 2003 & HIV & Viral envelope glycoprotein \\
\hline DB01319 & Fosamprenavir & Small molecule & 2003 & HIV & Viral protease \\
\hline DB00442 & Entecavir & Small molecule & 2005 & HBV & DNA \\
\hline DB00932 & Tipranavir & Small molecule & 2005 & HIV & Viral protease \\
\hline DB01264 & Darunavir & Small molecule & 2006 & HIV & Viral protease \\
\hline DB01265 & Telbivudine & Small molecule & 2006 & HBV & Viral DNA polymerase, DNA \\
\hline DB04835 & Maraviroc & Small molecule & 2007 & HIV & Human CCR5 \\
\hline DB06817 & Raltegravir & Small molecule & 2007 & HIV & Viral integrase \\
\hline DB06414 & Etravirine & Small molecule & 2008 & HIV & Viral reverse transcriptase \\
\hline DB08873 & Boceprevir & Small molecule & 2011 & $\mathrm{HCV}$ & Viral NS3 protein \\
\hline DB08864 & Rilpivirine & Small molecule & 2011 & HIV & Viral reverse transcriptase \\
\hline DB05521 & Telaprevir & Small molecule & 2011 & HCV & Virus NS3-4A protease \\
\hline
\end{tabular}

Abbreviations: CMV cytomegalovirus, HBV hepatitis B virus, $H C V$ hepatitis C virus, HSV herpes simplex virus, IFNAR interferon alpha/beta receptor, RSV respiratory syncytial virus, VZV varicella zoster virus.

analyses, such as virulence factors versus other factors [11] and oncogenic versus non-oncogenic factors [12-14], and the differential targeting of crucial intracellular pathways $[15,16]$.

One successful FDA-approved host-targeting antiviral drug is Maraviroc, a CCR5 chemokine receptor antagonist for the treatment of HIV infection [17] (Table 1). Other antivirals are being designed to target viral receptors, but a challenging and promising strategy is the use of preexisting small molecules to drug intracellular interactors of viral proteins that have been initially designed to treat other diseases. Considering the exponentially

Table 2 Databases of virus-host protein-protein interactions and drug-targets

\begin{tabular}{|c|c|c|c|c|}
\hline \multicolumn{5}{|l|}{ VH PPI databases } \\
\hline Name (reference) & Description & \multicolumn{2}{|c|}{ VH interactions } & Search date \\
\hline IntAct/MINT [87] & $\begin{array}{l}\text { Open-data molecular-interaction database populated by data curated either } \\
\text { from the literature or from direct data depositions }\end{array}$ & \multicolumn{2}{|c|}{$\begin{array}{l}\text { 5,717 (query performed through } \\
\text { IMEx single entry-point) }\end{array}$} & July 2014 \\
\hline DIP [88] & $\begin{array}{l}\text { Database that catalogs experimentally determined protein interactions that } \\
\text { are either curated or computationally extracted }\end{array}$ & & & \\
\hline Uniprot [89] & $\begin{array}{l}\text { Protein sequence reference database. Among numerous annotations are } \\
\text { listed some binary protein interactions quality-filtered from IntAct }\end{array}$ & & & \\
\hline VirusMentha [51] & $\begin{array}{l}\text { Resource that specifically captures and presents interactions between viral } \\
\text { and host proteins curated by databases that are part of the IMEx consortium }\end{array}$ & 5,846 & & October 2014 \\
\hline VirHostNet [52] & $\begin{array}{l}\text { Knowledge base dedicated to literature- and database-curated interactions } \\
\text { between viral and human proteins }\end{array}$ & 3,113 & & July 2014 \\
\hline \multicolumn{5}{|l|}{ Drug-target databases } \\
\hline Name (reference) & Description & Drugs & Targets & Search date \\
\hline DrugBank [90] & $\begin{array}{l}\text { High-quality knowledgebase. Provides extensive information on drugs, their } \\
\text { mechanisms of action and their associations with targets }\end{array}$ & 7,739 & 4,092 & July 2014 \\
\hline $\begin{array}{l}\text { Therapeutic Target } \\
\text { Database [91] }\end{array}$ & $\begin{array}{l}\text { Conceptually similar to DrugBank. Provides links between primary therapeutic } \\
\text { targets and their corresponding drugs }\end{array}$ & 20,667 & 2,360 & July 2014 \\
\hline ChEMBL [92] & $\begin{array}{l}\text { Large-scale database dedicated to the description of biological activities of } \\
\text { numerous chemical entities with drug-like properties, manually curated from } \\
\text { the medicinal chemistry literature }\end{array}$ & $1,359,508$ & 9,414 & July 2014 \\
\hline
\end{tabular}


growing number of candidate cellular targets from interactome studies, such drug repositioning is becoming a potentially more efficient way to increase the therapeutic antiviral arsenal.

Here, we will review and discuss recent advances in approaches for high-throughput VH PPI screening and the implications of these recent findings for understanding the landscape of VH PPI. We will describe the main insights for basic research as well as the potential for antiviral drug discovery. Finally, we feature some examples of promising and successful antiviral molecules targeting host proteins.

\section{Approaches for high-throughput screening of virus-host protein-protein interactions}

Since the first descriptions of $\mathrm{VH}$ protein interactions in the late 1980s, the associated methodologies have been adapted to large-scale studies. Yeast two-hybrid $(\mathrm{Y} 2 \mathrm{H})$ and co-affinity purification remain the most frequently used technologies, while protein arrays and proteincomplementation assays are emerging as promising approaches. As high-throughput data production does not have a universally accepted definition, we have chosen to review technologies that have generated more than $100 \mathrm{VH}$ PPIs. Using this definition, 35 reports can be referred to as HTS of VH PPIs since 2007 (Figure 1).

Since the pioneering description of the $\mathrm{Y} 2 \mathrm{H}$ approach in 1989 by Fields and Song [18], Y2H and its various technological improvements have been among the methods of choice for the construction of $\mathrm{VH}$ interactomes (Figure 2a). The first two unbiased genome-wide
VH PPI screens using $\mathrm{Y} 2 \mathrm{H}$ technology were performed for Epstein-Barr virus and $\mathrm{HCV}$. These studies relied on an initial construction of a viral ORFeome, comprising cloned open reading frames (ORFs) encoding a complete set of viral proteins, and led to the identification, respectively, of 173 and 314 VH PPIs [19,20]. The $\mathrm{Y} 2 \mathrm{H}$ technology has been used in 15 high-throughput screens since these founding studies, for viral genomewide interactome exploration or for focusing on a subset of viral proteins (Figure 1). Construction of viral and human ORFeome collections and implementation of versatile recombinational cloning systems (such as Gateway (Life Technologies, Gaithersburg, MD, USA)) are essential tools that have allowed this approach to become particularly powerful. For example, Shapira and colleagues [21] tested the interactions between the 10 influenza virus proteins and 12,000 human proteins available in the human ORFeome v3.1 [22]. The versatility of the Gateway system allows easy transfer of cDNAs into any compatible expression system for further interaction or functional studies. The ViralORFeome database was constructed to provide the scientific community with an integrated set of bioinformatics tools enabling the potential capture of viral ORFs in the Gateway recombinational cloning system and to make available a collection of viral cDNAs in Gatewaycompatible plasmids [23]. Nevertheless, interactions discovered using $\mathrm{Y} 2 \mathrm{H}$ screens must be confirmed by a secondary method, such as co-affinity purification, to reduce the risk of false-positive interactions and to increase the confidence in the dataset, which is usually expected to reach $>80 \%$ [20]. The problem of false-negative interactions is more difficult to address - the sensitivity of this

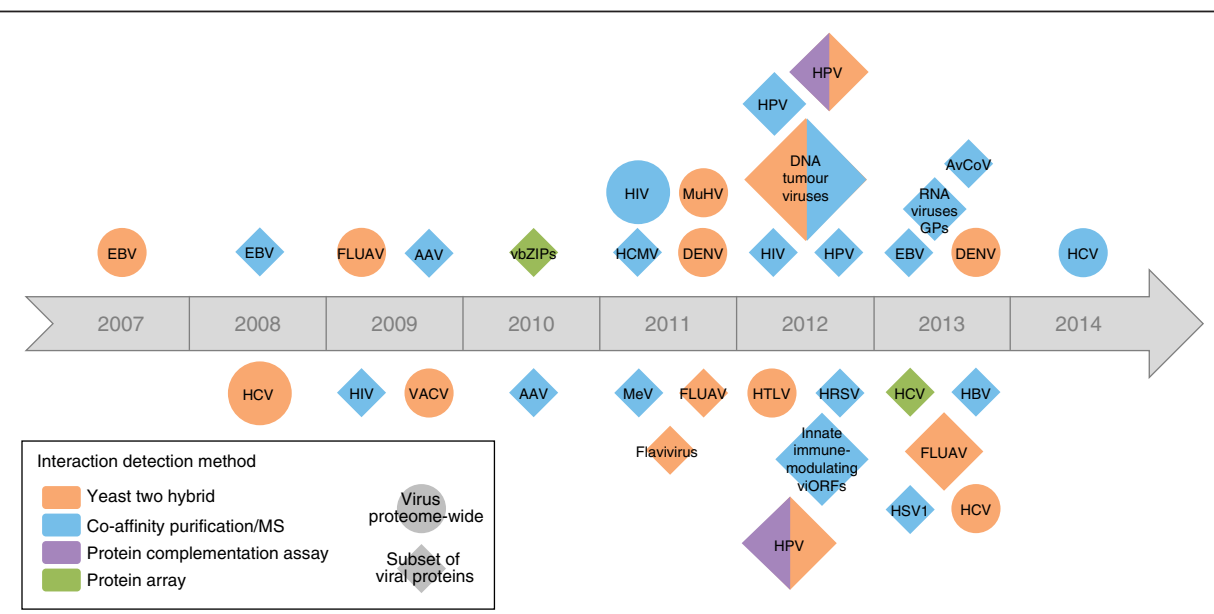

Figure 1 Timeline of studies describing the results of virus-host protein-protein interactions high-throughput screens. Circles indicate virus proteome-wide screens. Diamonds show studies of a particular subset of viral proteins. The various colors indicate the type of detection method used. The size of each shape is approximately proportional to the number of VH PPIs detected. Abbreviations: AAV, adeno-associated virus; CMV, cytomegalovirus; DENV, dengue virus; EBV, Epstein Barr virus; FLUAV, influenza A virus; GP, glycoprotein; HBV, hepatitis B virus; HCV, hepatitis C virus; HIV, human immunodeficiency virus; HRSV, human respiratory syncytial virus; HSV1, herpes simplex virus 1; HPV; human papillomavirus; HTLV, human T-lymphotropic virus; ORF, open reading frame; RSV, respiratory syncytial virus; VACV, vaccinia virus; VZV, varicella zoster virus. 
(a) Yeast two-hybrid

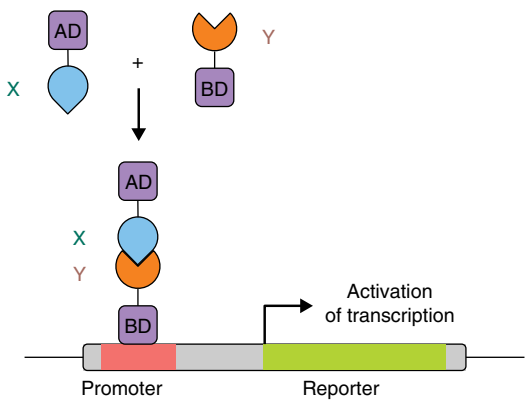

(c) Protein array

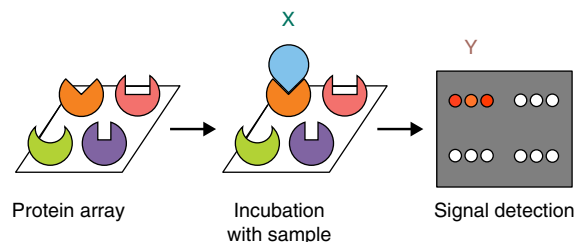

(b) Co-affinity purification/MS

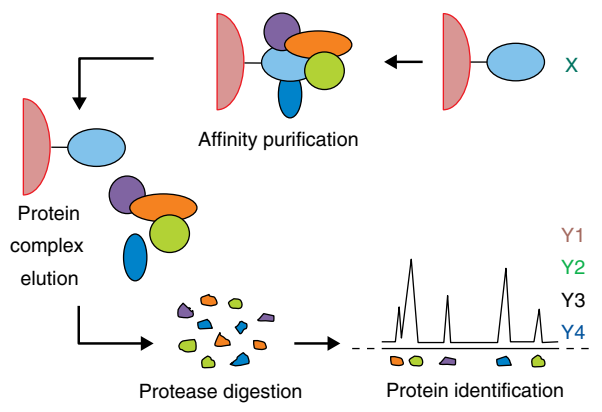

(d) Protein complementation assay

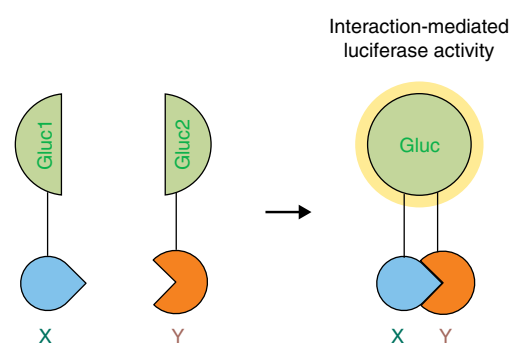

Figure 2 Methods used for high-throughput screening of virus-host protein-protein interactions. (a) The yeast two-hybrid approach. The generic principle of a $\mathrm{Y} 2 \mathrm{H}$ system is based on the reconstitution of a functional transcription factor following interaction between a bait protein and a prey protein. One construct comprises the DNA-binding domain of the transcription factor (BD) in fusion with a bait protein, whereas the prey protein is fused with the transcription activation domain (AD). Upon interaction of the bait with the prey in the nucleus of the yeast, the transcription factor activity is reconstituted, leading to the transcription of a reporter gene. In general, reporter genes are selected for their ability to allow the growth of yeast on selective medium or the use of a colorimetric assay so that their active transcription can be easily monitored. Bait and prey interactions can be tested pairwise in an array when both baits and preys have been individually cloned or upon the screening of fusion proteins expressed from cDNA libraries followed by sequencing of selected preys. (b) The co-affinity purification/MS technique. This approach is typically divided into two technical steps consisting of the capture of cellular proteins with the bait protein and identification of affinity-purified proteins by mass spectrometry (MS; method reviewed in [86]). (c) The protein array. Functional protein arrays, also called 'protein chips', can comprise a thousand different proteins attached at high density on a solid surface [30]. Following binding of a protein of interest with its target, the interaction can be detected with fluorescent, radioisotope or photochemical tags. (d) Protein-complementation assays. These assays employ a split Gaussia princeps luciferase (Gluc) assay together with bait and prey proteins that are expressed in mammalian cells in fusion with two inactive fragments of the luciferase. Interaction between bait and prey brings the two fragments into close proximity, restoring the enzymatic activity.

technology does not exceed $25 \%$ [24], so that repetitive samplings of the same search space are mandatory to reach completeness.

While $\mathrm{Y} 2 \mathrm{H}$ screens tend to detect transient binary interactions, co-affinity purification coupled to mass spectrometry (coAP/MS) assays aim at detecting stable complexes [25], exploring overlapping and complementary interaction search spaces (Figure 2b). One major strength of this method, compared with $\mathrm{Y} 2 \mathrm{H}$, is that it can be performed under more-physiological conditions, allowing context-dependent identification of interactions. The tandem affinity purification (TAP) technique is a variation of co-affinity purification that is characterized by a lower contaminating background [26]. The TAP strategy involves the use of two tags and two sequential steps of affinity purification. This method has been used to generate the largest numbers of VH PPI data, for the targeting of host proteins by viral immune modulators [27] and by tumor virus proteins [13] that identified, respectively, 1,681 and 3,787 VH protein associations (Figure 1).

Protein array technologies emerged in 2010 as a promising approach to study VH PPI (Figures 1 and 2c). In a first screen, an original array was printed with human and viral leucine zipper regions of 33 human basic leucine zipper domain proteins and four viral proteins. By probing with fluorescently labeled versions of the same proteins, 101 interactions were detected [28]. This approach was well validated by circular dichroism (CD) spectroscopy that determines whether there are changes in the conformation of proteins when they interact. Use of $\mathrm{CD}$ confirmed all the retested interactions. A second screen performed in 2013 used a commercial human protein microarray kit containing 9,000 human proteins that identified 100 interactions with the HCV core protein as a probe [29]. This technology is rapidly evolving to improve sensitivity, to increase proteome coverage and 
to allow the development of label-free optical tools and the quantification of the association-dissociation rate of protein interactions in a high-throughput format [30]. More recently, HTS of VH PPI by using a protein complementation assay has been implemented by Jacob and coworkers (Figures 1 and 2d) [12,14]. Comparative VH interactomes were explored for E2, E6 and E7 proteins from a range of pathogenic and non-pathogenic human papillomaviruses. Benchmarking this method with random protein pairs and a positive reference set confirmed the performance of this assay in a high-throughput setting [31].

Because the presence of false positives and false negatives is inherent to HTS, quality control of the datasets is a major issue. Multiple approaches have been developed for the $\mathrm{Y} 2 \mathrm{H}$ strategies, including the diversification of reporter genes, low plasmid copy number and retesting hits by subcloning ORFs into fresh yeast [11,32-34], that have greatly helped to improve the quality of the datasets. A database of cDNAs considered to be false positives for the classic $\mathrm{Y} 2 \mathrm{H}$ system is also available as a work in progress [35] thanks to the work of Golemis and co-workers [36]. In a related attempt, last year the CRAPome database, a repository of common contaminants in coAP/MS experiments, was constructed to allow better characterization of background associated with this technology (for example, proteins that bind to the bead matrix used during the precipitation, antibodies conjugated to the beads or the epitope tag) [37]. Recent technical improvements also contributed to lower the rate of contaminants, and one of these techniques is known as 'stable isotope labeling with amino acids in cell culture' (SILAC) [38] coupled to co-affinity purification. SILAC is a powerful tool to discriminate background from specific interactions. Cells expressing the protein of interest and control cells are labeled with different non-radioactive isotopes (heavy $(\mathrm{H})$ and light $(\mathrm{L})$ ). The quantification of the $\mathrm{H}: \mathrm{L}$ ratio of proteins co-purified with the bait protein allows the relative quantification of recovered proteins. Nonspecific binding leads to a ratio of 1 , whereas a high ratio indicates a possible specific interaction. This method has been successfully applied to the interactomic mapping of the nucleocapsid protein from highly pathogenic North American porcine reproductive and respiratory syndrome virus [39], the human respiratory syncytial virus NS1 protein [40], the coronavirus infectious bronchitis nucleocapsid protein [41], the HIV1 Gag protein [42], NS3 and NS5 proteins of dengue virus type 2 [43], and NS1 and NS2 proteins of influenza A virus [44].

These approaches are complementary and allow the exploration of different interaction search spaces. Other methods have also been developed to be amenable to a high-throughput format. Among them, MAPPIT is a cytokine-based mammalian PPI trap assay [45] and
LUMIER is a tag-precipitation assay coupled to renilla luciferase [46]. To our knowledge, none of these methods has yet been applied in a high-throughput VH PPI study.

\section{Access to the comprehensive landscape of viral human protein targets}

Systems biology and reductionist approaches are complementary to build a comprehensive landscape of viral infection and replication. High-throughput screening has revealed a large number of $\mathrm{VH}$ PPIs, and numerous studies have also provided detailed and often mechanistically oriented information on specific $\mathrm{VH}$ interactions. Therefore, it is a challenge to identify the wealth of $\mathrm{VH}$ PPI data that are available in the literature. Several databases have been developed to capture and structure these data, either through text mining or through manual curation [47]. The International Molecular Exchange (IMEx) consortium can be considered the key public curator of such data, focusing on manually curated data to ensure the high-quality datasets that are required for further analysis [48]. Created in 2005, this international collaboration framework now coordinates most of the major public-interaction data providers. They share the literature curation workload, applying high-level quality standards and provide the scientific community with unique access to the data [48]. The IMEx strategy limits redundancies as well as inconsistencies and improves curation coverage. IMEx partners have adopted a common curation policy that entails the use of the controlled vocabularies and formats first standardized by the Human Proteome Organization (HUPO) Proteomics Standards Initiative - Molecular Interaction (PSI-MI) working group in 2002 [49].

VH PPIs are represented by nearly 6,000 non-redundant physical interactions highlighted by searching the available databases (IntAct/MINT, DIP and Uniprot, searched between July and October 2014; Table 2). VH PPIs are also accessible in VirusMentha, an iteration of the interactome browser mentha that presents non-redundant virusrelated interactions extracted from manually curated PPI databases that have adhered to the requirements of the IMEX consortium [50,51] (Table 2). Finally, the VirHostNet database also offers a high-quality dataset of approximately 3,100 curated VH PPIs but has not been updated since 2009 [52] (Table 2).

Additional efforts to construct a clean repository of VH PPIs have been made but are difficult to trace because they often result from isolated initiatives. For several years, we have been performing our own manual curation of VH PPIs in the literature, according to PSIMI standards. From our own experience, this is a highly demanding task, especially when it comes to viruses for which species, strains and protein identifiers have to be 
clearly defined, and because mature proteins are often not identified in viral polyprotein sequences. Papers with large datasets are also often difficult to process because of their inconvenient format and because of the heterogeneity in protein-annotation systems.

The number of publications describing VH PPIs is now over 3,000, involving more than 200 viral species (Figure 3a). The identification of non-redundant $\mathrm{VH}$ PPIs has been growing exponentially since 2007, with the use of HTS methods (Figures 1 and 3a). The accumulation of VH PPIs also might allow increased confidence in interactions that are redundantly described in the literature.

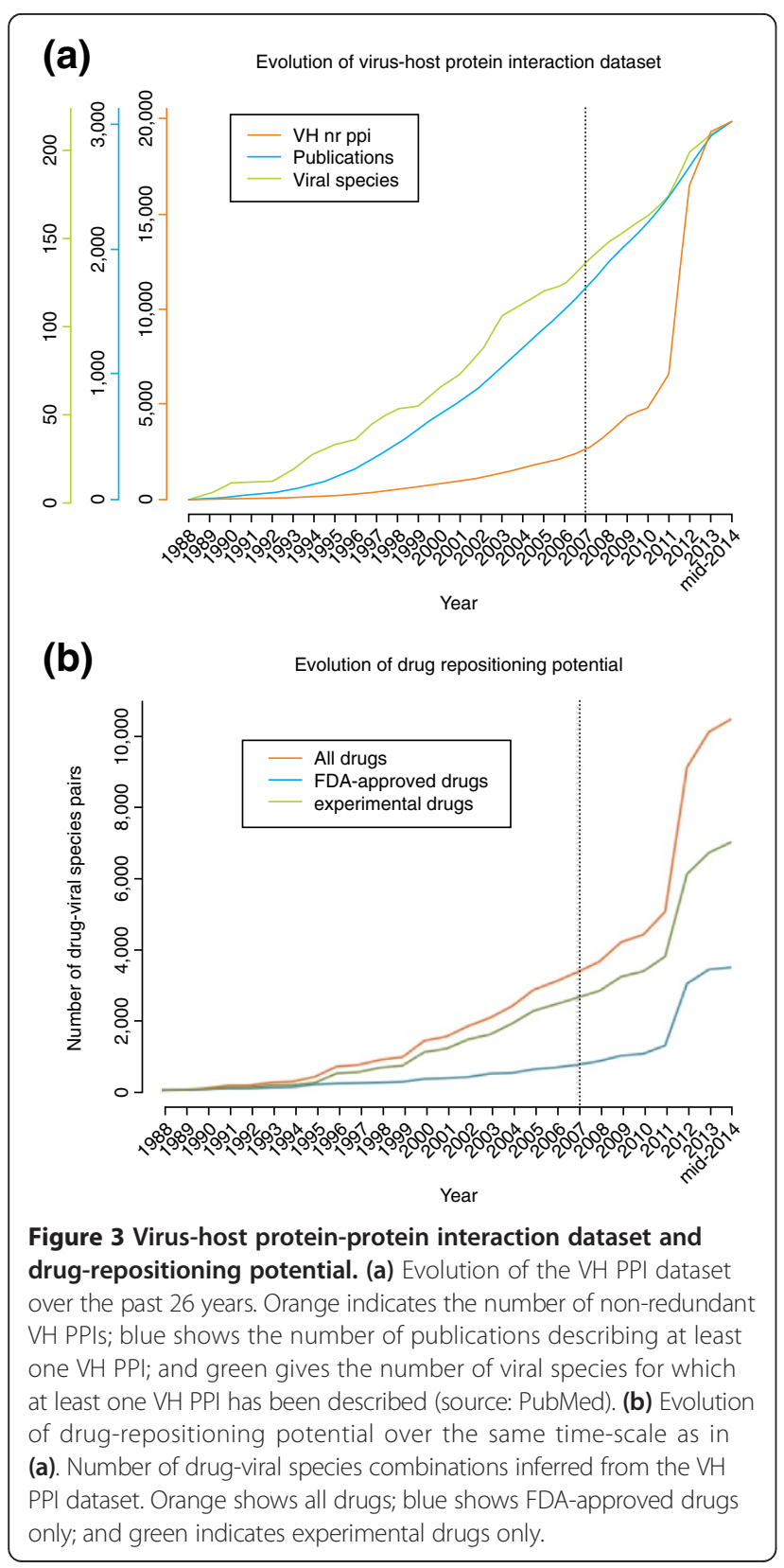

Despite efforts to gain confidence in HTS data, overlaps between VH PPI datasets are often very low. Experimental protocols are not yet standardized from lab to lab, from the choice of technology to differences in scoring cutoffs. For instance, if $\mathrm{Y} 2 \mathrm{H}$ has been the most popular strategy so far to construct $\mathrm{VH}$ interactomes, technological variations of this generic approach are very important at different essential steps, such as the reporter genes, yeast strains, plasmid copy number, fusion proteins, stringency conditions and libraries, that have an obvious impact on the outcome of the experiment [53]. Another important consideration is the dynamic nature of many VH PPIs during the course of the infection. For instance, Sindbis virus nsP3 protein has been shown to interact with several heterogeneous nuclear ribonucleoproteins primarily at the early times of infection, whereas interactions with 14-3-3 epsilon, zeta and eta were only observed at later times during infection [53]. Sindbis virus nsP4 protein was found associated with five specific host factors at early times in infection and ten others at later times [54]. This highlights the importance of the physiological context evolving during the infection and that can also differ according to the type of cells and the conditions of infection. Independent of the technology, an important variable that could influence the overlap between VH screens is the heterogeneity of the virus protein sequences. This is mostly exemplified for RNA viruses, whose polymerases display a high mutation rate [55]. As a consequence, an RNA virus referred to as a primary isolate is not genetically homogeneous. The sequence of a viral protein can be highly divergent from the sequence of a reference protein, and this could be responsible for the loss or gain of interactions. Finally, some interactions might be missed owing to inherent limitations of the technologies that are used. For instance, $\mathrm{Y} 2 \mathrm{H}$ is not compatible with membrane proteins or with self-activating proteins, and some interactions might require post-translational modifications from mammalian cells. Tags or reporter proteins that are fused with baits or preys can cause steric hindrance and prevent protein interactions. To gain confidence in a biophysical interaction, orthogonal validations using other interaction methods are therefore required so that a confidence score can be calculated [24]. After more than two decades of studying VH PPIs, the overlap of recent screens for the most-studied viruses with previous studies is now reaching 25\% (HCV [56], influenza virus NS1 protein [44]). Bearing the above considerations in mind, it is possible that this rate of overlap defines a nearcomplete dataset of cellular proteins that are in interaction with an extensively studied virus.

$\mathrm{VH}$ interactomes are representative of which interactions might occur during the infection but do not unambiguously identify biologically relevant cellular targets 
before a functional validation of the interactions. The functional validation is mostly assessed by modulating the expression levels of cellular proteins (overexpression, knockout or knockdown). In a recent exploration of HCV-host PPIs, RNA interference screening of viral protein interactors revealed that $21.7 \%$ were essential for viral replication [56]. This rate of validation is in the range of previous work [11,21] and is well above the rates identified from genome-wide small interfering RNA screens (between 0.45\% [57] and 1.36\% [58]). This indicates that combining interactomics with functional genomics strongly enhances the biological relevance of a cellular protein for the replication of a virus. It should also be considered that, instead of modulating the quantity of a given cellular protein, anti-viral molecules will rather be designed to inhibit a catalytic cellular activity or to prevent a viral protein from interacting with one or several cellular partners. Therefore, although the combination of high-throughput strategies could help reduce the number of drug-target candidates in a funnel effect, a drawback is the possible emergence of falsenegative targets and the exclusion of potentially interesting drug candidates.

\section{Recent insights from virus-human interactome studies}

High-throughput screening studies of $\mathrm{VH}$ interactions were initially implemented to provide a comprehensive view of the interplay between a virus and its host. For example, mapping of the HCV infection protein network has shed new light on the molecular basis of the coderegulation of insulin, Jak-STAT and transforming growth factor beta signaling pathways involved in the most frequent clinical syndromes, and it has identified the specific targeting of the focal adhesion pathway, thus providing new avenues for the study of tumor initiation and progression [20].

Other screens have been designed to identify the differential strategies exploited by closely related viruses to perturb the cellular network. Comparative interactomics of human papillomavirus E2 proteins clustered these proteins according to the pathogenic potential of the viral strains (high-risk versus low-risk), giving clues to the potential of therapies targeting specific proteins [14]. The TAP approach has been applied to profile the interactome of 70 viral immune modulators from 30 viral species, identifying an unexpected variety of cellular mechanisms exploited by individual viruses, families and groups [27]. Simultaneously, a systematic study of DNA $\mathrm{VH}$ interactomes (including papillomavirus, Epstein-Barr virus, adenovirus and polyomavirus, using both $\mathrm{Y} 2 \mathrm{H}$ screens and TAP tag purifications) and transcriptome network perturbations revealed a rewiring of the cellular network and highlighted the Notch signaling pathway and deregulation of apoptosis in virus-induced cancer [13]. The first comparative mapping of interactions of a set of influenza A virus NS1 and NS2 proteins, chosen for their sequence diversity, revealed cellular targets involved in each step of the infectious process that are shared by all or the majority of the viral proteins [11].

Beyond the establishment of $\mathrm{VH}$ interactomes and the discovery of specific and common cellular functions targeted by viruses, studies have revealed the fundamental principles that have evolved by which viruses manipulate the cellular network $[5,10,59,60]$. Computational analysis of network-descriptive metrics (such as 'degree' and 'betweenness') raised striking observations regarding the centrality of viral targets in the context of the human protein network. Indeed, viral proteins showed a preferential interaction with high-degree cellular proteins that is, proteins having a high number of direct interacting partners that are therefore locally highly connected in the human interactome. Viral proteins also have a strong tendency to interact with cellular proteins of high betweenness, which is a global centrality measure of the number of shortest paths that pass through a given protein and reflects the flux of information that is controlled by that protein. These topological characteristics of cellular proteins targeted by viral proteins have been observed from unbiased high-throughput $\mathrm{VH}$ interaction screenings and are indicative of the functional importance of these characteristics. Another general hallmark of viruses is that they can compensate for their small proteomes by the ability to interact with numerous cellular proteins. To allow this, they have evolved intrinsically disordered protein regions that are enriched for short linear motifs involved in multiple interactions in the human protein network [10,61]. Some of these motifs are adopted from the characteristics of their host by using a strategy of molecular mimicry (for example, the PDZ-binding motif at the carboxyl terminus of avian influenza NS1 proteins [62] and the polyproline motif on the HCV NS5A protein that is able to interact with Srchomology 3 (SH3) domains of cellular proteins [63]).

Taken together, proteomic analyses are boosting our knowledge of viral replication and disease etiology and are allowing the identification of new cellular targets that might be suitable for drug development.

\section{Advances in targeting viral interactors}

\section{Antiviral drug discovery shifts towards host targets}

The search for effective therapeutics to treat viral infections has been an active area of research for many years, resulting in both success and failure. Chronic infections by viruses such as HIV or hepatitis B virus (HBV) can now be controlled, but they require lifelong treatment. Treatments for acute viral infections - for example, by respiratory viruses or highly pathogenic emerging RNA 
viruses - are either poorly effective or do not exist. Overall, the treatment of viral infections largely remains an unmet medical need despite intense research activity. In addition to targeting viral components through directacting drugs (Table 1), recent efforts are now focusing on the identification of essential host factors as the targets of new antivirals. Targeting host factors dramatically enlarges the repertoire of therapeutic targets and offers a greater barrier to the emergence of resistance. Targeting host molecules has the potential for broad-spectrum indications when targeting pathways that are shared by the different variants of a given virus or by different types of virus [10]. Although far from complete, the construction of $\mathrm{VH}$ interactomes is starting to support this active field to identify the best cellular proteins to be targeted for an antiviral activity.

\section{Targeting human proteins}

Antiviral small molecules that inhibit cellular functions or VH PPIs have been reported in the literature, but currently no database has been developed to reference them. Below, we review a selection of host-oriented molecules with antiviral activity in vitro or in vivo against two major viruses infecting humans, influenza and HCVs.

The antiviral market is worth more than US\$4 billion and has a high growth rate. Recurrent seasonal influenza represents a significant part of this market, with 5 to $10 \%$ of the world population being infected each year by the influenza virus. A highly effective pan-strain vaccination remains the major objective to protect the population from this infection. Currently, protection relies on annual vaccination, offering variable and unpredictable efficacy, and on the antiviral neuraminidase inhibitors oseltamivir and zanamavir, which can be used for the treatment of established illness and for pre- and postexposure prophylaxis in specific situations. However, the effectiveness of these drugs is strongly questioned, and the emergence of resistance and changes in seasonal and pandemic strains further decrease drug response. Because of the limited therapeutic options for epidemic and pandemic influenza, novel approaches to the development of influenza drugs are a public health priority.

Inhibiting influenza virus replication with drugs that target cellular proteins or cellular functions is now an established concept. Early studies first used these drugs for basic research $[64,65]$, but, soon after, inhibitors of protein kinase $C$ (PKC) and the Raf-MEK-ERK signaling cascades were tested for their therapeutic potential $[66,67]$. Since then, more than 80 compounds targeting host proteins have been identified for their inhibitory impact on influenza virus replication (Figure 4). These compounds target a large diversity of cellular proteins, acting at almost all steps of the virus replication cycle.
Many of these inhibitory molecules were originally developed for anti-cancer indications and include agents such as MEK inhibitors [8], obatoclax and gemcitabine [68], flavopiridol [69], anti-cytoskeletal drugs [70] and etoposide [71], among others. Most of these drugs have an inherent toxicity when tested for long-term treatment, but it should be noted that treatment of severe influenza virus infections is not expected to last more than a few days. For treatment of non-severe influenza infections, additional molecules are actively being sought, and several extended interactomes that have identified more than 600 cellular targets of viral proteins are providing useful leads $[11,21,44,51]$.

As mentioned above, a major problem in the use of direct-acting drugs for the treatment of viral infections is the high frequency of emergence of resistant strains. The development of host-targeted therapies is expected to reduce this risk. This has been tested experimentally by repetitive culture of influenza virus under pressure of direct-acting or host-oriented drugs. After five to ten passages, no reduction of the antiviral effect was observed using host-oriented molecules (a MEK inhibitor [72], inhibitors of NF- $\mathrm{kB}[3,73]$ or an inhibitor of Rac1 [74]), whereas the use of the direct-acting drugs oseltamivir or amantadine (the two classes of approved drugs for the treatment of influenza) led to rapid emergence of resistant variants. This indicates that the virus cannot easily adapt to a situation where cellular functions that are essential for its replication become less accessible and further suggests that targeting the host confers a greater barrier to the development of viral resistance. Currently, LASAG (lysine acetyl salicylate glycine) is the first molecule targeting host intracellular proteins (NF$\kappa \mathrm{B})$ that is undergoing phase II clinical trials for the treatment of severe influenza virus infection [75]. Inhibitors of NF- $\mathrm{kB}$ are expected to limit the production of deleterious cytokines during an infection with highly pathogenic influenza viruses [76].

Virus-host PPIs also provide huge potential for the development of antiviral molecules that directly interfere with the $\mathrm{VH}$ interactions. Experimental molecules that disrupt VH PPIs have already been investigated for various viruses, and several pharmaceutical and biotechnology companies have projects focusing on the identification and development of drugs against host targets and $\mathrm{VH}$ PPIs (Table 3). Alisporivir is one of the most advanced molecules of this kind that has reached phase III trials for anti-HCV therapy, as part of interferon-free treatment combinations in chronic hepatitis $\mathrm{C}$ genotype 1 patients (however, the FDA has put the trial on hold to assess a possible side-effect of pancreatitis). Phase II trial recruitments for chronic hepatitis $C$ genotypes 2 and 3 are ongoing [77]. The drug is a non-immunosuppressive derivative of cyclosporin $\mathrm{A}(\mathrm{CsA})$ for which the precise 


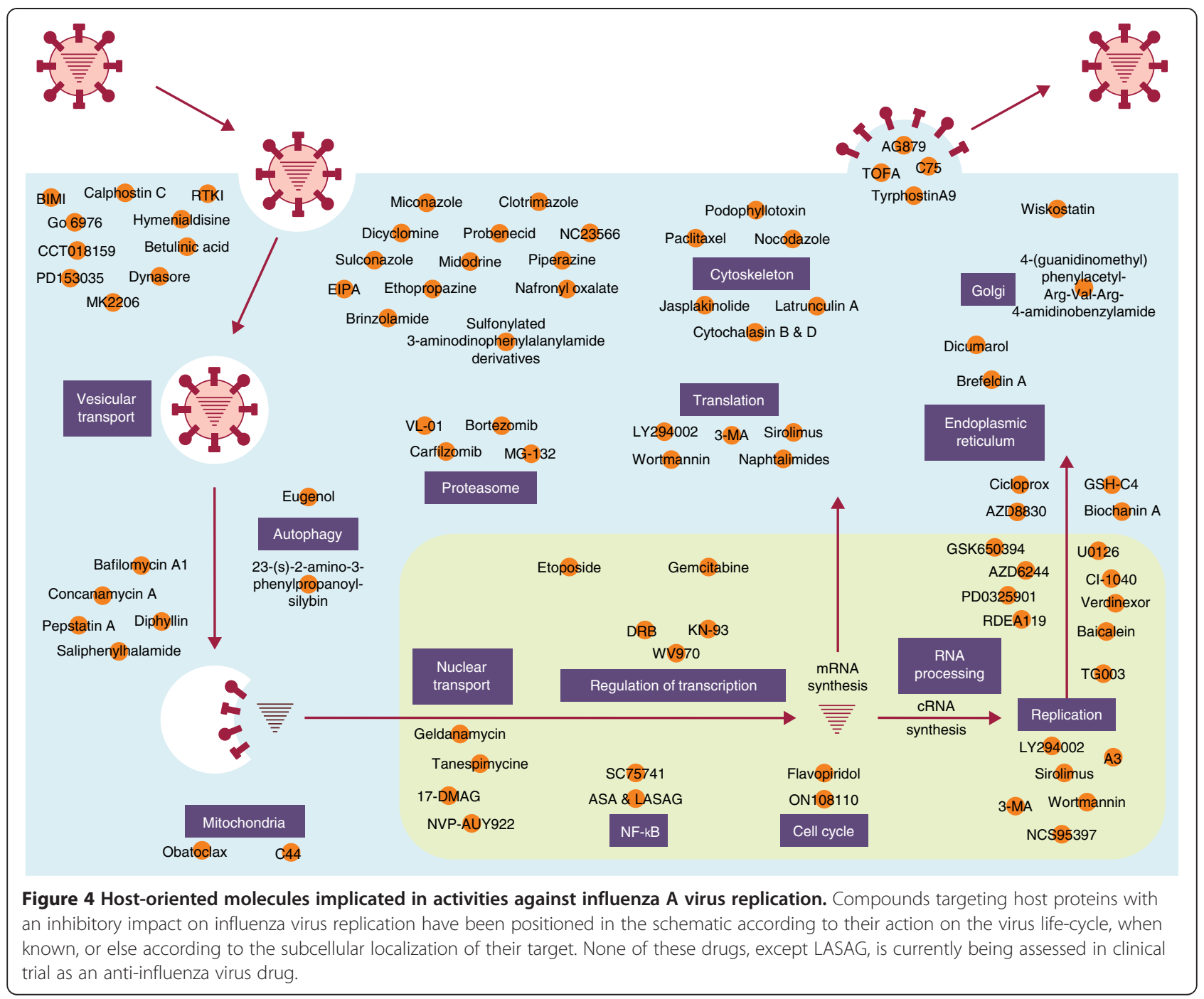

mechanism of action against $\mathrm{HCV}$ infection was initially unknown [78]. Later, it was shown that CsA disrupts the interaction between cyclophilin A and NS5A through its binding in the peptidyl-prolyl isomerase hydrophobic pocket of cyclophilin A $[79,80]$. Use of alisporivir also provides a high barrier to the emergence of resistance, with multiple mutations in domain II of NS5A required in vitro for $\mathrm{HCV}$ to become resistant [81]. Even if interference of VH PPIs by small molecules proves to be effective for specific anti-viral indications, accumulation of further successful examples will be necessary for this approach to have widespread applicability.

To date, no molecule targeting an intracellular host protein is FDA approved for an antiviral indication. Thus, whether such drugs are truly suitable for the treatment of viral infections remains an open question, mostly because of potential side effects. Nevertheless, it is worth noting that the conventional antiviral compounds are actually quite toxic. Moreover, the duration of the treatment, mostly for acute infections such as with influenza viruses, is not expected to exceed a few days, and this could moderate the incidence of side effects and their severity.

\section{Drug repositioning}

The discovery of new antivirals can be accelerated and rationalized by integrating $\mathrm{VH}$ interactomes and drugrelated databases. A VH PPI repertoire is indicative of the cellular proteins that are essential for the replication of a given virus. Therefore, these cellular proteins can be considered as potential therapeutic targets whose function could be manipulated by existing small molecules to prevent viral usage and interfere with viral replication. Such modulators of cellular functions, either approved by government authorities or in clinical development for other indications, could be repositioned as new antiviral agents $[4,6-9]$. 
Table 3 Biotechnology companies working on the drugs against host targets and virus-host protein-protein interations

\begin{tabular}{|c|c|c|c|c|c|}
\hline Company & Web site & Location & Viral application & Stage & Mode of action \\
\hline Inhikibase Therapeutics & www.inhibikase.com & Atlanta (GA, USA) & $\begin{array}{l}\text { Polyomaviruses, } \\
\text { HCV, HBV, smallpox } \\
\text { virus, ebola virus, } \\
\text { RSV, rhinovirus }\end{array}$ & $\mathrm{NC}$ & $\mathrm{NC}$ \\
\hline Forge Life Science & $\begin{array}{l}\text { www.forgelifescience. } \\
\text { com }\end{array}$ & Doyleston (PA, USA) & $\begin{array}{l}\text { JCV, BKV, CMV, } \\
\text { seasonal flu }\end{array}$ & Research & $\begin{array}{l}\text { Enhances the innate } \\
\text { role of human sirtuins }\end{array}$ \\
\hline $\begin{array}{l}\text { Ciclofilin } \\
\text { Pharmaceuticals }\end{array}$ & www.ciclofilin.com & San Diego (CA, USA) & $\begin{array}{l}\text { HCV/HBV/HIV } \\
\text { co-infection }\end{array}$ & Preclinical & Inhibitors of cyclophilin \\
\hline Gemmus Pharma & $\begin{array}{l}\text { www.gemmuspharma. } \\
\text { com }\end{array}$ & $\begin{array}{l}\text { San Francisco (CA, } \\
\text { USA) }\end{array}$ & FLUAV & NC & $\begin{array}{l}\text { Agonist of a G } \\
\text { protein-coupled } \\
\text { receptor }\end{array}$ \\
\hline $\begin{array}{l}\text { Springbank } \\
\text { Pharmaceuticals }\end{array}$ & $\begin{array}{l}\text { www.springbankpharm. } \\
\text { com }\end{array}$ & Milford (MA, USA) & $\mathrm{HCV}$ and $\mathrm{HBV}$ & Phase 1 & $\begin{array}{l}\text { Activates RIG1 and } \\
\text { NOD2 }\end{array}$ \\
\hline iTherX & www.itxpharma.com & San Diego (CA, USA) & HCV (liver transplant) & Phase 1 & Entry inhibitors \\
\hline Prosetta Biosciences & www.prosetta.com & $\begin{array}{l}\text { San Francisco (CA, } \\
\text { USA) }\end{array}$ & $\begin{array}{l}\text { HCV, FLUAV, HIV1, } \\
\text { RABV }\end{array}$ & SAR & $\begin{array}{l}\text { Targets viral capsid host } \\
\text { protein interaction }\end{array}$ \\
\hline OyaGen Inc & www.oyageninc.com & Rochester (NY, USA) & HIV1 & Pre-clinical & $\begin{array}{l}\text { APOBEC } 3 G \text { activation and } \\
\text { Vif-APOBEC3G interaction }\end{array}$ \\
\hline Microbiotix & www.microbiotix.com & Worcester (MA, USA) & Ebola virus & Discovery & $\begin{array}{l}\text { Targets NPC1-glycoprotein } \\
\text { interaction }\end{array}$ \\
\hline Enyo Pharma & www.enyopharma.com & Lyon (France) & $\begin{array}{l}\text { HBV, FLUAV, Ebola } \\
\text { virus }\end{array}$ & $\begin{array}{l}\text { Lead } \\
\text { optimization }\end{array}$ & NC \\
\hline Scynexis & www.scynexis.com & Durham (NC, USA) & $\mathrm{HCV}$ & Phase 2 & Inhibitors of cyclophilin \\
\hline Vectura & www.vectura.com & Germany and UK & Severe FLUAV & Phase 2 & Inhibitor of NF-KB \\
\hline Novartis & www.novartis.com & Multinational & $\mathrm{HCV}$ & Phase 2 and 3 & $\begin{array}{l}\text { Cyclophilin A-NS5A } \\
\text { interaction }\end{array}$ \\
\hline
\end{tabular}

Abbreviations: BKV BK virus, HBV hepatitis B virus. HCV hepatitis $C$ virus, CMV cytomegalovirus, FLUAV influenza A virus, JCV John Cunningham virus, NC not communicated; RABV, rabies virus; RSV, respiratory syncytial virus.

Databases that collect information on bioactive small molecules and their protein targets are numerous and differ mainly in their focus and detail level (Table 2). A first comparison of these resources highlights that they are both specific and complementary [82]. However, their standardization in terms of targets and most of all in terms of chemical entities remains a crucial challenge [83]. A preliminary attempt to aggregate several drug-gene interaction resources is available in the druggene interaction database (DGIdb), a database that allows the exploration of the human druggable genome [84].

Combining the evolving VH PPI dataset with the drugtarget interactions described in DrugBank has already revealed the great potential of drug repurposing for the discovery of antiviral molecules (Figure $3 \mathrm{~b}$ ). This potential has been accelerating since the first high-throughput screenings for VH PPIs.

\section{Conclusions and perspectives}

Since 2007, high-throughput technologies have been applied to $\mathrm{VH}$ interactomes, and the number of PPIs and human targets has been growing exponentially ever since. Overall, this new dataset paves the way for the comprehensive understanding of virus life-cycles and host-cell responses. It also opens new horizons for the discovery of host-oriented drugs, whereas most of the antiviral molecules developed so far have only targeted viral components. Basic and pharmaceutical research is now moving towards the targeting of host proteins. Successful examples include the FDA-approved Maraviroc for the treatment of HIV infection, and promising results, for example, for influenza (LASAG, phase II clinical trial, Vectura, Chippenham, UK) and hepatitis C (Alisporivir, phase II clinical trial, Novartis, Basel, Switzerland). These pioneering studies have also demonstrated a reduction in the rate of emergence of antiviral resistance. The explosion in the number of potential targets owing to the recent use of high-throughput technologies has also resulted in an explosion in the number of antiviral drug candidates through the use of repositioning strategies for existing drugs and experimental molecules.

Virus-host interactomes are far from complete and would greatly benefit from the diversification of proteininteraction detection methods to allow the comprehensive exploration of the interactome space. Another major concern is the quality and completeness of the human interactome itself, which is important for prioritizing targets 
and for proposing strategies of drug combinations based on network pharmacology.

Viruses have evolved with their hosts to manipulate numerous cellular functions, and much can also be learnt from them to control cellular functions that are impaired in non-infectious pathologies. For instance, bioenergetic metabolism plays a pivotal role in the replication of viruses, and the targeting of metabolism by viral proteins can translate into clinical symptoms, best exemplified by chronic hepatitis $\mathrm{C}$, which is characterized by metabolic dysfunction, including insulin resistance. Interestingly, the activity of hexokinase, the first rate-limiting enzyme of glycolysis, is increased upon its interaction with a $\mathrm{HCV}$ protein [85]. Mimicking the mechanisms by which this viral protein controls the first step of glycolysis should make it possible to develop novel therapeutic strategies to potentiate glycolysis in metabolic diseases. Testing the hypothesis that genomic mutations and tumor viruses might cause cancer through related mechanisms, RozenblattRosen and colleagues [13] showed that the analysis of the cellular targets of tumor virus proteins can identify cancer genes with a good success rate. Combined with genomic studies, tumor $\mathrm{VH}$ interactomes could therefore become instrumental for the identification of cancer-related genes and proteins and for their prioritization for therapeutic development. These are just two examples from recent studies that indicate that, in addition to paving the way to host-oriented therapeutics for the treatment of viral infections, $\mathrm{VH}$ interactomes also have broad implications for the field of non-infectious diseases.

\section{Abbreviations \\ CD: Circular dichroism; coAP/MS: Co-affinity purification coupled to mass spectrometry; CsA: Cyclosporin A; FDA: Food and Drug Administration; HBV: Hepatitis B virus; HCV: Hepatitis C virus; HTS: High-throughput screening; HUPO: Human Proteome Organization; IMEx: International Molecular Exchange; LASAG: Lysine acetyl salicylate glycine; ORF: Open reading frame; PPI: Protein-protein interaction; PSI-MI: Proteomics Standards Initiative - Molecular Interaction; SILAC: Stable isotope labeling with amino acid in cell culture; TAP: Tandem affinity purification; VH: Virus-host; Y2H: Yeast two-hybrid.}

\section{Competing interests}

PA and VL have financial interests in ENYO Pharma SAS.

\section{Acknowledgments}

The authors wish to acknowledge their past and current collaborators at Inserm U1111. Research in the authors' laboratory is supported by the European Union's Seventh Program (FP7/2007-2013) under grant agreement no. 267429 (SysPatho).

\section{Author details}

${ }^{1}$ ENYO Pharma SAS, Lyon 69007, France. ${ }^{2}$ Hospices Civils de Lyon, Lyon, France. ${ }^{3}$ CIRI, Université de Lyon, Lyon 69365, France. ${ }^{4}$ Inserm, U1111, Lyon 69365, France.

Published online: 29 November 2014

\section{References}

1. Kieffer $T L$, George $S$ : Resistance to hepatitis $C$ virus protease inhibitors. Curr Opin Virol 2014, 8C:16-21.
2. Pennings PS: HIV drug resistance: problems and perspectives. Infect Dis Rep 2013, 5:e5.

3. Van der Vries E, Schutten M, Fraaij P, Boucher C, Osterhaus A: Influenza virus resistance to antiviral therapy. Adv Pharmacol 2013, 67:217-246.

4. De Chassey B, Meyniel-Schicklin L, Aublin-Gex A, André P, Lotteau V: New horizons for antiviral drug discovery from virus-host protein interaction networks. Curr Opin Virol 2012, 2:606-613.

5. Dyer MD, Murali TM, Sobral BW: The landscape of human proteins interacting with viruses and other pathogens. PLoS Pathog 2008, 4:e32.

6. Pfefferle S, Schöpf J, Kögl M, Friedel CC, Müller MA, Carbajo-Lozoya J, Stellberger T, von Dall'Armi E, Herzog P, Kallies S, Niemeyer D, Ditt V, Kuri T, Züst R, Pumpor K, Hilgenfeld R, Schwarz F, Zimmer R, Steffen I, Weber F,

Thiel V, Herrler G, Thiel H-J, Schwegmann-Wessels C, Pöhlmann S, Haas J, Drosten C, von Brunn A: The SARS-coronavirus-host interactome: identification of cyclophilins as target for pan-coronavirus inhibitors. PLOS Pathog 2011, 7:e1002331.

7. García-Dorival I, Wu W, Dowall S, Armstrong S, Touzelet O, Wastling J, Barr JN, Matthews D, Carroll M, Hewson R, Hiscox JA: Elucidation of the Ebola virus VP24 cellular interactome and disruption of virus biology through targeted inhibition of host cell protein function. J Proteome Res 2014, 13:5120-5135.

8. Planz O: Development of cellular signaling pathway inhibitors as new antivirals against influenza. Antiviral Res 2013, 98:457-468.

9. De Chassey B, Meyniel-Schicklin L, Aublin-Gex A, André P, Lotteau V: Genetic screens for the control of influenza virus replication: from meta-analysis to drug discovery. Mol Biosyst 2012, 8:1297-1303.

10. Meyniel-Schicklin L, de Chassey B, André P, Lotteau V: Viruses and interactomes in translation. Mol Cell Proteomics 2012, 11:M111.014738.

11. De Chassey B, Aublin-Gex A, Ruggieri A, Meyniel-Schicklin L, Pradezynski F, Davoust N, Chantier T, Tafforeau L, Mangeot P-E, Ciancia C, Perrin-Cocon L, Bartenschlager $R$, André $P$, Lotteau $V$ : The interactomes of influenza virus NS1 and NS2 proteins identify new host factors and provide insights for ADAR1 playing a supportive role in virus replication. PLoS Pathog 2013, 9:e1003440.

12. Neveu G, Cassonnet P, Vidalain P-O, Rolloy C, Mendoza J, Jones L, Tangy F, Muller M, Demeret C, Tafforeau L, Lotteau V, Rabourdin-Combe C, Travé G, Dricot A, Hill DE, Vidal M, Favre M, Jacob Y: Comparative analysis of virus-host interactomes with a mammalian high-throughput protein complementation assay based on Gaussia princeps luciferase. Methods 2012, 58:349-359.

13. Rozenblatt-Rosen $\mathrm{O}$, Deo RC, Padi M, Adelmant G, Calderwood MA, Rolland T, Grace M, Dricot A, Askenazi M, Tavares M, Pevzner SJ, Abderazzaq F, Byrdsong D, Carvunis A-R, Chen AA, Cheng J, Correll M, Duarte M, Fan C, Feltkamp MC, Ficarro SB, Franchi R, Garg BK, Gulbahce N, Hao T, Holthaus AM, James R, Korkhin A, Litovchick L, Mar JC, et al: Interpreting cancer genomes using systematic host network perturbations by tumour virus proteins. Nature 2012, 487:491-495.

14. Muller M, Jacob $Y$, Jones $L$, Weiss $A$, Brino $L$, Chantier $T$, Lotteau V, Favre $M$ Demeret C: Large scale genotype comparison of human papillomavirus E2-host interaction networks provides new insights for e2 molecular functions. PLoS Pathog 2012, 8:e1002761.

15. Grégoire IP, Richetta C, Meyniel-Schicklin L, Borel S, Pradezynski F, Diaz O, Deloire A, Azocar O, Baguet J, Le Breton M, Mangeot PE, Navratil V, Joubert P-E, Flacher M, Vidalain P-O, André P, Lotteau V, Biard-Piechaczyk M, Rabourdin-Combe C, Faure M: IRGM is a common target of RNA viruses that subvert the autophagy network. PLoS Pathog 2011, 7:e1002422.

16. Navratil V, de Chassey B, Meyniel L, Pradezynski F, André P, RabourdinCombe C, Lotteau V: System-level comparison of protein-protein interactions between viruses and the human type I interferon system network. J Proteome Res 2010, 9:3527-3536.

17. Dorr P, Westby M, Dobbs S, Griffin P, Irvine B, Macartney M, Mori J, Rickett G, Smith-Burchnell C, Napier C, Webster R, Armour D, Price D, Stammen B, Wood A, Perros M: Maraviroc (UK-427,857), a potent, orally bioavailable, and selective small-molecule inhibitor of chemokine receptor CCR5 with broad-spectrum anti-human immunodeficiency virus type 1 activity. Antimicrob Agents Chemother 2005, 49:4721-4732.

18. Fields S, Song O: A novel genetic system to detect protein-protein interactions. Nature 1989, 340:245-246.

19. Calderwood MA, Venkatesan K, Xing L, Chase MR, Vazquez A, Holthaus AM, Ewence AE, Li N, Hirozane-Kishikawa T, Hill DE, Vidal M, Kieff E, Johannsen E: Epstein-Barr virus and virus human protein interaction maps. Proc Natl Acad Sci U S A 2007, 104:7606-7611. 
20. De Chassey B, Navratil V, Tafforeau L, Hiet MS, Aublin-Gex A, Agaugué S, Meiffren G, Pradezynski F, Faria BF, Chantier T, Le Breton M, Pellet J, Davoust $N$, Mangeot $P E$, Chaboud A, Penin F, Jacob Y, Vidalain PO, Vidal M, André $P$, Rabourdin-Combe C, Lotteau V: Hepatitis C virus infection protein network. Mol Syst Biol 2008, 4:230.

21. Shapira SD, Gat-Viks I, Shum BOV, Dricot A, de Grace MM, Wu L, Gupta PB, Hao T, Silver SJ, Root DE, Hill DE, Regev A, Hacohen N: A physical and regulatory map of host-influenza interactions reveals pathways in $\mathrm{H} 1 \mathrm{~N} 1$ infection. Cell 2009, 139:1255-1267.

22. Lamesch P, Li N, Milstein S, Fan C, Hao T, Szabo G, Hu Z, Venkatesan K, Bethel G, Martin P, Rogers J, Lawlor S, McLaren S, Dricot A, Borick H, Cusick ME, Vandenhaute J, Dunham I, Hill DE, Vidal M: hORFeome v3.1: a resource of human open reading frames representing over 10,000 human genes. Genomics 2007, 89:307-315.

23. Pellet J, Tafforeau L, Lucas-Hourani M, Navratil V, Meyniel L, Achaz G, Guironnet-Paquet A, Aublin-Gex A, Caignard G, Cassonnet P, Chaboud A, Chantier T, Deloire A, Demeret C, Le Breton M, Neveu G, Jacotot L, Vaglio P, Delmotte S, Gautier C, Combet C, Deleage G, Favre M, Tangy F, Jacob Y, Andre P, Lotteau V, Rabourdin-Combe C, Vidalain PO: ViralORFeome: an integrated database to generate a versatile collection of viral ORFs. Nucleic Acids Res 2010, 38:D371-D378.

24. Braun P, Tasan M, Dreze M, Barrios-Rodiles M, Lemmens I, Yu H, Sahalie JM, Murray RR, Roncari L, de Smet A-S, Venkatesan K, Rual J-F, Vandenhaute J, Cusick ME, Pawson T, Hill DE, Tavernier J, Wrana JL, Roth FP, Vidal M: An experimentally derived confidence score for binary protein-protein interactions. Nat Methods 2009, 6:91-97.

25. Yu H, Braun P, Yildirim MA, Lemmens I, Venkatesan K, Sahalie J, HirozaneKishikawa T, Gebreab F, Li N, Simonis N, Hao T, Rual J-F, Dricot A, Vazquez A, Murray RR, Simon C, Tardivo L, Tam S, Svrzikapa N, Fan C, de Smet A-S, Motyl A, Hudson ME, Park J, Xin X, Cusick ME, Moore T, Boone C, Snyder M, Roth FP, et al: High-quality binary protein interaction map of the yeast interactome network. Science 2008, 322:104-110.

26. Rigaut G, Shevchenko A, Rutz B, Wilm M, Mann M, Séraphin B: A generic protein purification method for protein complex characterization and proteome exploration. Nat Biotechnol 1999, 17:1030-1032.

27. Pichlmair A, Kandasamy K, Alvisi G, Mulhern O, Sacco R, Habjan M, Binder M, Stefanovic A, Eberle C-A, Goncalves A, Bürckstümmer T, Müller AC, Fauster A, Holze C, Lindsten K, Goodbourn S, Kochs G, Weber F, Bartenschlager R, Bowie AG, Bennett KL, Colinge J, Superti-Furga G: Viral immune modulators perturb the human molecular network by common and unique strategies. Nature 2012, 487:486-490.

28. Reinke AW, Grigoryan G, Keating AE: Identification of bZIP interaction partners of viral proteins HBZ, MEQ, BZLF1, and K-bZIP using coiled-coil arrays. Biochemistry 2010, 49:1985-1997.

29. Ngo HTT, Pham LV, Kim J-W, Lim Y-S, Hwang SB: Modulation of mitogen-activated protein kinase-activated protein kinase 3 by hepatitis C virus core protein. J Virol 2013, 87:5718-5731.

30. Uzoma I, Zhu H: Interactome mapping: using protein microarray technology to reconstruct diverse protein networks. Genomics Proteomics Bioinformatics 2013, 11:18-28.

31. Cassonnet P, Rolloy C, Neveu G, Vidalain P-O, Chantier T, Pellet J, Jones L, Muller M, Demeret C, Gaud G, Vuillier F, Lotteau V, Tangy F, Favre M, Jacob Y: Benchmarking a luciferase complementation assay for detecting protein complexes. Nat Methods 2011, 8:990-992.

32. Parrish JR, Gulyas KD, Finley RL: Yeast two-hybrid contributions to interactome mapping. Curr Opin Biotechnol 2006, 17:387-393.

33. Dolan PT, Zhang C, Khadka S, Arumugaswami V, Vangeloff AD, Heaton NS, Sahasrabudhe S, Randall G, Sun R, LaCount DJ: Identification and comparative analysis of hepatitis $C$ virus-host cell protein interactions. Mol Biosyst 2013, 9:3199-3209.

34. Mairiang D, Zhang $H$, Sodja A, Murali T, Suriyaphol P, Malasit $P$, Limjindaporn T, Finley RL: Identification of new protein interactions between dengue fever virus and its hosts, human and mosquito. PLOS One 2013, 8:e53535.

35. Interaction Trap At Work [http://www.fccc.edu/research/labs/golemis/ InteractionTraplnWork.html]

36. Golemis EA, Serebriiskii I, Finley RL, Kolonin MG, Gyuris J, Brent R: Interaction trap/two-hybrid system to identify interacting proteins. Curr Protoc Cell Biol 2011, Chapter 17:Unit 17.3.

37. Mellacheruvu D, Wright Z, Couzens AL, Lambert J-P, St-Denis NA, Li T, Miteva YV, Hauri S, Sardiu ME, Low TY, Halim VA, Bagshaw RD, Hubner NC,
Al-Hakim A, Bouchard A, Faubert D, Fermin D, Dunham WH, Goudreault M, Lin Z-Y, Badillo BG, Pawson T, Durocher D, Coulombe B, Aebersold R, Superti-Furga G, Colinge J, Heck AJR, Choi H, Gstaiger M, et al: The CRAPome: a contaminant repository for affinity purification-mass spectrometry data. Nat Methods 2013, 10:730-736.

38. Ong S-E, Mann M: Mass spectrometry-based proteomics turns quantitative. Nat Chem Biol 2005, 1:252-262.

39. Jourdan SS, Osorio F, Hiscox JA: An interactome map of the nucleocapsid protein from a highly pathogenic North American porcine reproductive and respiratory syndrome virus strain generated using SILAC-based quantitative proteomics. Proteomics 2012, 12:1015-1023.

40. Wu W, Tran KC, Teng MN, Heesom KJ, Matthews DA, Barr JN, Hiscox JA: The interactome of the human respiratory syncytial virus NS1 protein highlights multiple effects on host cell biology. J Virol 2012, 86:7777-7789.

41. Emmott E, Munday D, Bickerton E, Britton P, Rodgers MA, Whitehouse A, Zhou E-M, Hiscox JA: The cellular interactome of the coronavirus infectious bronchitis virus nucleocapsid protein and functional implications for virus biology. J Virol 2013, 87:9486-9500.

42. Engeland $C E$, Brown NP, Börner $K$, Schümann $M$, Krause E, Kaderali L, Müller GA, Kräusslich H-G: Proteome analysis of the HIV-1 Gag interactome. Virology 2014, 460-461:194-206.

43. Carpp LN, Rogers RS, Moritz RL, Aitchison JD: Quantitative proteomic analysis of host-virus interactions reveals a role for Golgi brefeldin A resistance factor 1 (GBF1) in dengue infection. Mol Cell Proteomics 2014, 13:2836-2854.

44. Tawaratsumida K, Phan V, Hrincius ER, High AA, Webby R, Redecke V, Häcker $H$ : Quantitative proteomic analysis of the influenza A virus nonstructural proteins NS1 and NS2 during natural cell infection identifies PACT as an NS1 target protein and antiviral host factor. J Virol 2014, 88:9038-9048.

45. Eyckerman S, Verhee A, der Heyden JV, Lemmens I, Ostade XV, Vandekerckhove J, Tavernier J: Design and application of a cytokine-receptor-based interaction trap. Nat Cell Bio/ 2001, 3:1114-1119.

46. Barrios-Rodiles M, Brown KR, Ozdamar B, Bose R, Liu Z, Donovan RS, Shinjo F, Liu Y, Dembowy J, Taylor IW, Luga V, Przulj N, Robinson M, Suzuki H, Hayashizaki Y, Jurisica I, Wrana JL: High-throughput mapping of a dynamic signaling network in mammalian cells. Science 2005, 307:1621-1625.

47. Klingström T, Plewczynski D: Protein-protein interaction and pathway databases, a graphical review. Brief Bioinform 2011, 12:702-713.

48. Orchard S, Kerrien S, Abbani S, Aranda B, Bhate J, Bidwell S, Bridge A, Briganti L, Brinkman FSL, Brinkman F, Cesareni G, Chatr-aryamontri A, Chautard E, Chen C, Dumousseau M, Goll J, Hancock REW, Hancock R, Hannick LI, Jurisica I, Khadake J, Lynn DJ, Mahadevan U, Perfetto L, Raghunath A, Ricard-Blum S, Roechert B, Salwinski L, Stümpflen V, Tyers $M$, et al: Protein interaction data curation: the International Molecular Exchange (IMEx) consortium. Nat Methods 2012, 9:345-350.

49. Kerrien S, Orchard S, Montecchi-Palazzi L, Aranda B, Quinn AF, Vinod N, Bader GD, Xenarios I, Wojcik J, Sherman D, Tyers M, Salama JJ, Moore S, Ceol A, Chatr-Aryamontri A, Oesterheld M, Stümpflen V, Salwinski L, Nerothin J, Cerami E, Cusick ME, Vidal M, Gilson M, Armstrong J, Woollard P, Hogue C, Eisenberg D, Cesareni G, Apweiler R, Hermjakob H: Broadening the horizon-level 2.5 of the HUPO-PSI format for molecular interactions. BMC Biol 2007, 5:44.

50. Calderone A, Castagnoli L, Cesareni G: Mentha: a resource for browsing integrated protein-interaction networks. Nat Methods 2013, 10:690-691.

51. Calderone A, Licata L, Cesareni G: VirusMentha: a new resource for virus-host protein interactions. Nucleic Acids Res. 2014. doi: 10.1093/nar/gku830.

52. Navratil V, de Chassey B, Meyniel L, Delmotte S, Gautier C, André P, Lotteau V, Rabourdin-Combe C: VirHostNet: a knowledge base for the management and the analysis of proteome-wide virus-host interaction networks. Nucleic Acids Res 2009, 37:D661-D668.

53. Cristea IM, Carroll J-WN, Rout MP, Rice CM, Chait BT, MacDonald MR: Tracking and elucidating alphavirus-host protein interactions. J Biol Chem 2006, 281:30269-30278.

54. Cristea IM, Rozjabek H, Molloy KR, Karki S, White LL, Rice CM, Rout MP, Chait BT, MacDonald MR: Host factors associated with the Sindbis virus RNA-dependent RNA polymerase: role for G3BP1 and G3BP2 in virus replication. J Virol 2010, 84:6720-6732

55. Duffy S, Shackelton LA, Holmes EC: Rates of evolutionary change in viruses: patterns and determinants. Nat Rev Genet 2008, 9:267-276.

56. Germain M-A, Chatel-Chaix L, Gagné B, Bonneil É, Thibault P, Pradezynski F, de Chassey B, Meyniel-Schicklin L, Lotteau V, Baril M, Lamarre D: Elucidating novel hepatitis $C$ virus-host interactions using combined mass 
spectrometry and functional genomics approaches. Mol Cell Proteomics 2014, 13:184-203.

57. Tai AW, Benita Y, Peng LF, Kim S-S, Sakamoto N, Xavier RJ, Chung RT: A functional genomic screen identifies cellular cofactors of hepatitis $C$ virus replication. Cell Host Microbe 2009, 5:298-307.

58. Li Q, Brass AL, Ng A, Hu Z, Xavier RJ, Liang TJ, Elledge SJ: A genome-wide genetic screen for host factors required for hepatitis $C$ virus propagation. Proc Natl Acad Sci U S A 2009, 106:16410-16415.

59. Law GL, Korth MJ, Benecke AG, Katze MG: Systems virology: host-directed approaches to viral pathogenesis and drug targeting. Nat Rev Microbiol 2013, 11:455-466

60. Segura-Cabrera A, García-Pérez CA, Guo X, Rodríguez-Pérez MA: A viral-human interactome based on structural motif-domain interactions captures the human infectome. PLoS One 2013, 8:e71526.

61. Hagai T, Azia A, Babu MM, Andino R: Use of host-like peptide motifs in viral proteins is a prevalent strategy in host-virus interactions. Cell Rep 2014, 7:1729-1739.

62. Jackson D, Hossain MJ, Hickman D, Perez DR, Lamb RA: A new influenza virus virulence determinant: the NS1 protein four C-terminal residues modulate pathogenicity. Proc Natl Acad Sci U S A 2008, 105:4381-4386.

63. Shelton $\mathrm{H}$, Harris M: Hepatitis C virus NS5A protein binds the SH3 domain of the Fyn tyrosine kinase with high affinity: mutagenic analysis of residues within the $\mathrm{SH} 3$ domain that contribute to the interaction. Virol J 2008, 5:24.

64. Rindler MJ, Ivanov IE, Sabatini DD: Microtubule-acting drugs lead to the nonpolarized delivery of the influenza hemagglutinin to the cell surface of polarized Madin-Darby canine kidney cells. J Cell Biol 1987, 104:231-241.

65. Ciampor F, Závodská E, Cmarko D, Cmarková J, Varecková E: Effects of brefeldin $A$ on the expression and transport of influenza $A$ virus haemagglutinin, M1 and M2 proteins within the cell. Acta Virol 1997 41:83-91.

66. Root CN, Wills EG, McNair LL, Whittaker GR: Entry of influenza viruses into cells is inhibited by a highly specific protein kinase $C$ inhibitor. J Gen Virol 2000, 81:2697-2705.

67. Pleschka S, Wolff T, Ehrhardt C, Hobom G, Planz O, Rapp UR, Ludwig S: Influenza virus propagation is impaired by inhibition of the Raf/MEK/ERK signalling cascade. Nat Cell Biol 2001, 3:301-305.

68. Denisova OV, Kakkola L, Feng L, Stenman J, Nagaraj A, Lampe J, Yadav B, Aittokallio T, Kaukinen P, Ahola T, Kuivanen S, Vapalahti O, Kantele A, Tynell J, Julkunen I, Kallio-Kokko H, Paavilainen H, Hukkanen V, Elliott RM, De Brabander JK, Saelens X, Kainov DE: Obatoclax, saliphenylhalamide, and gemcitabine inhibit influenza a virus infection. J Biol Chem 2012, 287:35324-35332

69. Wang S, Zhang J, Ye X: Protein kinase inhibitor flavopiridol inhibits the replication of influenza virus in vitro. Wei Sheng Wu Xue Bao 2012, 52:1137-1142.

70. Momose F, Kikuchi Y, Komase K, Morikawa Y: Visualization of microtubule-mediated transport of influenza viral progeny ribonucleoprotein. Microbes Infect 2007, 9:1422-1433

71. Henter J-I, Palmkvist-Kaijser K, Holzgraefe B, Bryceson YT, Palmér K: Cytotoxic therapy for severe swine flu A/H1N1. Lancet 2010, 376:2116.

72. Ludwig S, Wolff T, Ehrhardt C, Wurzer WJ, Reinhardt J, Planz O, Pleschka S: MEK inhibition impairs influenza $B$ virus propagation without emergence of resistant variants. FEBS Lett 2004, 561:37-43.

73. Mazur I, Wurzer WJ, Ehrhardt C, Pleschka S, Puthavathana P, Silberzahn T, Wolff T, Planz O, Ludwig S: Acetylsalicylic acid (ASA) blocks influenza virus propagation via its NF-kappaB-inhibiting activity. Cell Microbio/ 2007, 9:1683-1694.

74. Dierkes R, Warnking K, Liedmann S, Seyer R, Ludwig S, Ehrhardt C: The Rac1 inhibitor NSC23766 exerts anti-influenza virus properties by affecting the viral polymerase complex activity. PLoS One 2014, 9:e88520.

75. Vectura [http://www.vectura.com]

76. De Jong MD, Simmons CP, Thanh T, Hien VM, Smith GJD, Chau TNB, Hoang DM, Chau NW, Khanh TH, Dong VC, Qui PT, Cam Van B, Ha DQ, Guan Y, Peiris JSM, Chinh NT, Hien TT, Farrar J: Fatal outcome of human influenza A (H5N1) is associated with high viral load and hypercytokinemia. Nat Med 2006, 12:1203-1207.

77. Novartis [http://www.novartis.com]

78. Inoue K, Sekiyama K, Yamada M, Watanabe T, Yasuda H, Yoshiba M: Combined interferon alpha2b and cyclosporin $A$ in the treatment of chronic hepatitis C: controlled trial. J Gastroenterol 2003, 38:567-572.
79. Gallay PA, Lin K: Profile of alisporivir and its potential in the treatment of hepatitis C. Drug Des Devel Ther 2013, 7:105-115

80. Lim PJ, Gallay PA: Hepatitis C NS5A protein: two drug targets within the same protein with different mechanisms of resistance. Curr Opin Virol 2014, 8C:30-37.

81. Garcia-Rivera JA, Bobardt M, Chatterii U, Hopkins S, Gregory MA, Wilkinson B, Lin K, Gallay PA: Multiple mutations in hepatitis C virus NS5A domain II are required to confer a significant level of resistance to alisporivir. Antimicrob Agents Chemother 2012, 56:5113-5121.

82. Southan C, Sitzmann M, Muresan S: Comparing the chemical structure and protein content of ChEMBL, DrugBank, Human Metabolome Database and the Therapeutic Target Database. Mol Inform 2013, 32:881-897.

83. Akhondi SA, Kors JA, Muresan S: Consistency of systematic chemical identifiers within and between small-molecule databases. J Cheminform 2012, 4:35

84. Griffith M, Griffith OL, Coffman AC, Weible JV, McMichael JF, Spies NC, Koval J, Das I, Callaway MB, Eldred JM, Miller CA, Subramanian J, Govindan R, Kumar RD, Bose R, Ding L, Walker JR, Larson DE, Dooling DJ, Smith SM, Ley TJ, Mardis ER, Wilson RK: DGIdb: mining the druggable genome. Nat Methods 2013, 10:1209-1210.

85. Ramière C, Rodriguez J, Enache LS, Lotteau V, André P, Diaz O: Activity of hexokinase is increased by its interaction with hepatitis $C$ virus protein NS5A. J Virol 2014, 88:3246-3254.

86. Gingras A-C, Gstaiger M, Raught B, Aebersold R: Analysis of protein complexes using mass spectrometry. Nat Rev Mol Cell Biol 2007, 8:645-654.

87. Orchard S, Ammari M, Aranda B, Breuza L, Briganti L, Broackes-Carter F, Campbell NH, Chavali G, Chen C, Del-Toro N, Duesbury M, Dumousseau M, Galeota E, Hinz U, lannuccelli M, Jagannathan S, Jimenez R, Khadake J, Lagreid A, Licata L, Lovering RC, Meldal B, Melidoni AN, Milagros M, Peluso D, Perfetto L, Porras P, Raghunath A, Ricard-Blum S, Roechert B, et al: The MlntAct project-IntAct as a common curation platform for 11 molecular interaction databases. Nucleic Acids Res 2014, 42:D358-D363.

88. Salwinski L, Miller CS, Smith AJ, Pettit FK, Bowie JU, Eisenberg D: The Database of Interacting Proteins: 2004 update. Nucleic Acids Res 2004, 32:D449-D451.

89. UniProt: a hub for protein information. Nucleic Acids Res. 2014 doi:10.1093/nar/gku989.

90. Law V, Knox C, Djoumbou Y, Jewison T, Guo AC, Liu Y, Maciejewski A, Arndt D, Wilson M, Neveu V, Tang A, Gabriel G, Ly C, Adamjee S, Dame ZT, Han B, Zhou Y, Wishart DS: DrugBank 4.0: shedding new light on drug metabolism. Nucleic Acids Res 2014, 42:D1091-D1097.

91. Qin C, Zhang C, Zhu F, Xu F, Chen SY, Zhang P, Li YH, Yang SY, Wei YQ, Tao L, Chen YZ: Therapeutic target database update 2014: a resource for targeted therapeutics. Nucleic Acids Res 2014, 42:D1118-D1123.

92. Bento AP, Gaulton A, Hersey A, Bellis L, Chambers J, Davies M, Krüger FA, Light Y, Mak L, McGlinchey S, Nowotka M, Papadatos G, Santos R, Overington JP: The ChEMBL bioactivity database: an update. Nucleic Acids Res 2014, 42:D1083-D1090.

doi:10.1186/s13073-014-0115-

Cite this article as: de Chassey et al: Virus-host interactomics: new insights and opportunities for antiviral drug discovery. Genome Medicine $20146: 115$ 